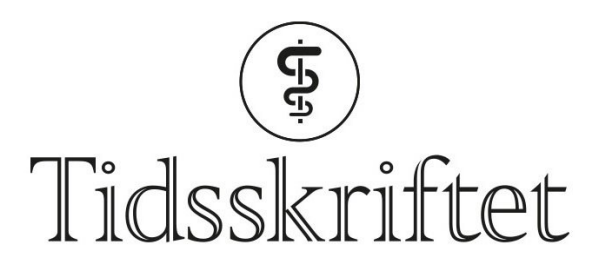

DEN NORSKE LEGEFORENING

\title{
Nytt år, nytt håp
}

MINILEDER

\section{ARE BREAN}

Sjefredaktør

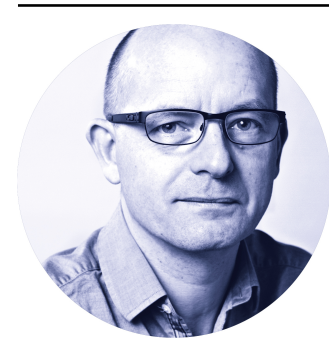

2020 var på mange måter et trist år for global helse. Heldigvis bringer 2021 flere håp. At koronavaksinene nå rulles ut, er en viktig milepæl i kampen mot viruset, selv om vaksinefordelingen foreløpig hverken er global eller rettferdig.

I skyggen av koronavaksinene nås en annen milepæl, i kampen mot en annen global helsetrussel. 22. januar 2021 trer nemlig FNs atomvåpenforbud i kraft. Bruk av atomvåpen har katastrofale humanitære effekter - som varer i generasjoner. 122 land har stemt for avtalen, som forbyr enhver befatning med atomvåpen. 50 land har hittil ratifisert den. Norge er ikke blant noen av disse. Men norske leger har bidratt. Verdens legeorganisasjon (World Medical Association) har vært sentral i arbeidet med forbudet, i Norge støttet av blant andre Legeforeningen og Norske leger mot atomvåpen.

Pandemien vi er midt inne i, har vist oss hvor sårbart både helsevesen og samfunn er for omfattende helsekriser. En atomkrig står blant de verst tenkelige av disse. Norske leger kan være stolte av å ha bidratt til FN-avtalen som nå trer i kraft. Arbeidet for å få Norge til å slutte seg til bør fortsette.

Publisert: 11. januar 2021. Tidsskr Nor Legeforen. DOI: 10.4045/tidsskr.21.01.01 (C) Tidsskrift for Den norske legeforening 2020. Lastet ned fra tidsskriftet.no 